\title{
Ultra-processed foods: Consumption among children at day-care centers and their classification according to Traffic Light Labelling system
}

\author{
Alimentos ultra-processados: consumo entre crianças \\ em creches públicas e análise da composição \\ nutricional segundo a ferramenta \\ "Traffic Light Labelling"
}

Giovana LONGO-SILVA'

Maysa Helena de Aguiar TOLONI ${ }^{2}$

Risia Cristina Egito de MENEZES ${ }^{1}$

Leiko ASAKURA ${ }^{3}$

Maria Alice Araújo OLIVEIRA ${ }^{3}$

José Augusto de Aguiar Carrazedo TADDEI ${ }^{4}$

A B S T R A C T

\section{Objective}

To identify the age at which ultra-processed foods are introduced in the diet of infants enrolled in public daycare centers and analyze these foods' nutritional composition according to the Traffic Light Labelling system adapted to the Brazilian norms and recommendations.

\section{Methods}

Cross-sectional study including 636 nursery age children attending day care centers. Their mothers were interviewed about the age of introduction of instant noodles, snack chips, encased meat, chocolate, ice cream,

\footnotetext{
1 Universidade Federal de Alagoas, Faculdade de Nutrição, Programa de Pós-Graduação em Nutrição. Campus AC Simões, Av. Lourival Melo Mota, s/n., Cidade Universitária, 57072-900, Maceió, AL, Brasil. Correspondência para/Correspondence to: GLONGO-SILVA. E-mail: <giovana_longo@yahoo.com.br>.

2 Universidade Federal de Lavras, Curso de Nutrição, Departamento de Ciências da Alimentação. Lavras, MG, Brasil.

3 Universidade Federal de Alagoas, Faculdade de Nutrição, Curso de Nutrição. Maceió, AL, Brasil.

${ }^{4}$ Universidade Federal de São Paulo, Departamento de Pediatria, Programa de Pós-Graduação em Pediatria. São Paulo, SP, Brasil.

Support: Fundação de Amparo à Pesquisa do Estado de São Paulo (nº 2006/02597-0) and ABBOTT Brazil.
} 
and stuffed cookies. The proximate composition of these foods was evaluated according to the Traffic Light Labelling adapted to the Brazilian norms and recommendations, which classifies total fat, saturated fat, trans fat, fiber, and sodium amounts as green, yellow, or red indicators.

\section{Results}

It was found that before 12 months of age $70.6 \%$ of children had consumed instant noodles, $65.9 \%$ snack chips, $54.7 \%$ encased meat, $67.1 \%$ chocolate, $36.9 \%$ ice cream, and $68.7 \%$ stuffed cookies. In addition, all foods were classified as red for saturated fat and sodium and $50.0 \%$ were classified as red for total fat.

\section{Conclusion}

The introduction of ultra-processed foods in the children's diets occurred early, but it is worth mentioning that such foods have an inadequate nutritional composition, contributing to the excess consumption of total fat, saturated fat, and sodium, as well as low fiber.

Keywords: Child daycare centers. Food consumption. Food habits. Industrialized foods. Infant.

\section{R E S U M O}

\section{Objetivo}

Identificar a idade de introdução de alimentos ultra-processados na alimentação de lactentes matriculados em creches públicas e analisar suas composições nutricionais segundo a ferramenta de classificação nutricional Traffic Light Labelling, adaptada às normas e recomendações brasileiras.

\section{Métodos}

Estudo transversal com 636 crianças de berçários de creches, cujas mães foram entrevistadas sobre idade de introdução de macarrão instantâneo, salgadinhos, embutidos, chocolate, sorvete e bolacha recheada. Avaliaram-se as composições centesimais desses alimentos comparando-as com a ferramenta Traffic Light Labelling, adaptada às normas e recomendações brasileiras. Esta ferramenta classifica as quantidades de gordura total, gordura saturada, gordura trans, fibra e sódio em verde, amarelo ou vermelho.

\section{Resultados}

Verificou-se que, antes dos 12 meses de idade, 70,6\% das crianças haviam consumido macarrão instantâneo, $65,9 \%$ salgadinhos, $54,7 \%$ embutidos, $67,1 \%$ chocolate, $36,9 \%$ sorvete e $68,7 \%$ bolacha recheada. Em adição, todos os alimentos foram classificados como vermelho para gordura saturada e sódio, e 50,0\% obteve classificação vermelha para gordura total.

\section{Conclusão}

A introdução dos alimentos ultra-processados ocorreu precocemente na dieta das crianças, ressaltando que os mesmos apresentaram composição nutricional inadequada, fornecendo excesso de gordura total, gordura saturada, sódio e baixa quantidade de fibras.

Palavras-chave: Creches. Consumo de alimentos. Hábitos alimentares. Alimentos industrializados. Lactente.

\section{INTRODUCTION}

Healthy diet set early in life is of utmost importance for proper growth and development of children, and it contributes in the short, medium, and long term to prevent nutritional deficiencies, especially with regard to specific needs such as iron-deficiency anemia and vitamin A deficiency; it also prevents chronic NonCommunicable Diseases (NCD) ${ }^{1}$.
In this regard, the Ministry of Health recommends, as a public health measure, the practice of exclusive breastfeeding for up to six months, with the timely introduction of complementary foods, which should harmonize color, taste, variety, ensuring food hygiene and physical accessibility and financial access. Mothers must avoid sugar, processed meats, soft drinks, sweets, foods high in fat and salt, additives, and artificial preservatives ${ }^{2}$ among others, during lactation. 
These recommendations result from the compelling association between ultra-processed food consumption coupled with sedentary lifestyle with poor nutritional status and the occurrence of early chronic NCD ${ }^{3}$.

Despite the harm it can inflict, many studies have found that the early introduction of ultra-processed foods - which are defined as those that are ready for consumption or heating with little or no preparation ${ }^{4}$ - and it is, in a global context, a common practice among children, having become an important public health problem nowadays ${ }^{5,6}$.

This scenario is often related to changes in lifestyle, few food and nutrition education practices followed by the institutions, media appeals, and problems associated with the nutrition labeling complexity - the way it is exhibited, leading to consumers with little knowledge and skills required to make appropriate food choices? ${ }^{7}$.

Given this scenario, a simple and intuitive proposal was created by the United Kingdom Food Standards Agency (FSA) in order to guide consumers in choosing healthier products ${ }^{8}$. Such proposal is the Traffic Light Labelling, which provides subsidies to add direct and practical information on the labels about the nutritional composition of the food, making it easier for laymen and children to understand them in order to get more balanced diets. This instrument was adapted to the Brazilian norms and recommendations, through which the amounts of total fat, saturated fat, trans fats, sugar, sodium, and dietary fiber are classified according to the Traffic Light Labelling 9 colors. Thus, the red signal indicates that the food contains excessive amount of the nutrient, the yellow signal indicates an average amount, and the green signal indicates low amount of the nutrient.

Given the aforementioned the present study aimed to identify the age at which ultraprocessed foods are introduced in the diet of infants enrolled in public daycare centers and to analyze these foods' nutritional composition according to the Traffic Light Labelling.

\section{METHODS}

The current research is based on two crosssectional studies: the first was conducted in 2007 and the second in 2010. These studies were conducted in the nurseries of eight public daycare centers belonging to the Education Coordination of Santo Amaro in São Paulo, Brazil. The centers were part of the "Crecheficiente" Project (Efficient Daycare Project) - "Impact of training teachers from public/philanthropic daycare centers on hygienic-dietary practices and on the health/ nutrition of infants". This project has, among others, the following objectives: qualify, improve, and update the health care and nutrition services provided by the daycare centers' educators to infants, and evaluate their knowledge acquisition according to the activities they have prepared.

This study included 36 daycare centers that belong to the Education Coordinating Board of the district of Santo Amaro, in the city of São Paulo, Brazil. In the first stage of sample selection, daycare centers were contacted by telephone and personal visit. The daycare centers which had previously participated in a health-related study, did not have a nursery section, or refused to participate in this study were excluded, resulting in a total of 18 daycare centers. In the second stage of sample selection, the daycare centers were classified according to priority criteria ${ }^{10}$. The following criteria were prioritized in descending order of value: larger number of children, larger number of educators, safety of researchers, available transportation and easy access to the centers' facilities, and employment rules that ensure hiring low-income families only. Therefore, the eight highest ranked public daycare centers were selected.

Among the eight daycare centers selected for the 2007 study, one was excluded in 2010 due to lack of interest in participating during data collection. A total of 636 children (270 in 2007 and 366 in 2010), both male and female and aged 4-36 months, who regularly attended the nursery section of the selected daycare centers participated 
in the studies. The studies were conducted with parental and legal guardian consent by signing an Informed Consent Form agreeing to participate in the research.

The sample size (636 children), determined using the Epi Info (Atlanta, Georgia, United States, 2000), version 3.4.3, was large enough to obtain risk ratios around $1.1(\alpha=0.05$ and $\beta=0.2)$.

For the purpose of this study, ultraprocessed foods were considered as those ready to eat or ready to heat with little or no preparation; they result from the processing of several foodstuffs, including salting, sugaring, baking, frying, deep frying, curing, smoking, pickling, and canning with frequent use of preservatives and cosmetic additives, addition of synthetic vitamins and minerals, and sophisticated types of packaging. These type of products (chocolate, ice cream, stuffed cookies, instant noodles, snack chips, and encased meat are less perishable, but they contain high amount of fat, sugar, sodium, additives, and chemical preservatives ${ }^{4}$.

The introduction of foods such as instant noodles, snack chips, encased meat, chocolate, ice cream, stuffed cookies, was assessed in terms of their content and construct validity based on data collected using a structured, pre-coded, and pre-tested questionnaire. The questionnaire was composed of open and closed questions related to socioeconomic data, maternal indicators, and infants' feeding practices. The child age (months) of food introduction was recorded for all foods analyzed. Data collection was performed by four properly trained nutritionists, who interviewed the children's parents or guardians in the daycare centers on previously scheduled dates.

In order to standardize the instrument completion, a guidebook was prepared. It listed guidelines to interviewers and codified the variables. Data analysis included internal consistency, double entry, and validation. Statistical analyses were performed using the Epi Info software, version 3.4.3. In order to assess food introduction, the cumulative percentages were calculated per age group, mean, and standard deviation.

The proximate composition of the foods was evaluated using the Traffic Light Labelling9, which establishes cut-off points to classify the amounts of total, saturated and trans fats, sugar, fiber, and sodium present in $100 \mathrm{~g}$ of food, according to the colors red, yellow, or green. The average values for the nutrients on the nutrition facts label of the top five selling brands of each product were used to determine the proximate composition of ultra-processed foods.

The introduction of ice cream was investigated in 2010 only.

The current study was approved by the Research Ethics Committee of the Universidade Federal de São Paulo - CEP 0471/10.

\section{RES U LT S}

The median age of the children was 23 months ( 0 to 35 months). Among children evaluated $(n=636)$, there was a predominance of males (55.7\%), and a higher proportion of mothers aged 20-35 years old with a median age of $28 \pm 6.5$ years. As for maternal level of education, it was found that $36.0 \%$ of the mothers had less than eight years of schooling; $54.9 \%$ of the mothers were not qualified professionals or did not belong to the economically active population. With regard to family income, the median was $R \$ 1,000.00$, which is less than twice the minimum wage.

Table 1 shows the cumulative percentages per age group, mean, and standard deviation of introduction of ultra-processed foods. It was found that, before their first year of life, $70.6 \%$ of children had consumed instant noodles, $65.9 \%$ snack chips, $54.7 \%$ encased meat, $67.1 \%$ chocolate, $36.9 \%$ ice cream, and $68.7 \%$ stuffed cookies.

The results in Table 2 show the inadequate nutritional value of ultra-processed foods since all of them were classified as red for saturated fat and sodium, 50\% were classified as red for 
Table 1. Cumulative percentages per age group, mean, and standard deviation regarding the introduction of instant noodles, snack chips, and encased meat. São Paulo (SP), Brazil, 2007 and 2010.

\begin{tabular}{|c|c|c|c|c|c|c|c|c|}
\hline \multirow{3}{*}{ Foods } & \multicolumn{8}{|c|}{ Age of introduction (months) } \\
\hline & $0-6$ & $7-12^{*}$ & $12-36^{*}$ & Not introduced & Not informed & \multirow{2}{*}{$\begin{array}{c}\text { Total } \\
\mathrm{n}\end{array}$} & \multicolumn{2}{|c|}{ Months } \\
\hline & \multicolumn{5}{|c|}{$\%$} & & M & SD \\
\hline Instant noodles & 21.5 & 70.6 & 91.8 & 7.5 & 0.2 & 636 & 12.2 & 7.2 \\
\hline Snack chips & 8.6 & 65.9 & 94.0 & 5.7 & 0.3 & 636 & 14.1 & 6.9 \\
\hline Encased meat & 7.9 & 54.7 & 90.1 & 9.3 & 0.6 & 636 & 15.6 & 7.8 \\
\hline Chocolate & 10.7 & 67.1 & 96.7 & 3.3 & 0.0 & 636 & 13.7 & 6.9 \\
\hline Ice cream** & 2.2 & 36.9 & 66.4 & 32.8 & 0.8 & $366^{* *}$ & 15.6 & 6.1 \\
\hline Stuffed cookies & 13.5 & 68.7 & 93.4 & 5.8 & 0.8 & 636 & 13.3 & 7.2 \\
\hline
\end{tabular}

Note: ${ }^{*}$ Cumulative percentage; ${ }^{* *}$ Information collected in 2010 only.

M: Mean; SD: Standard Deviation.

Table 2. Classification of chocolate, ice cream, stuffed cookies, instant noodles, snack chips, and encased meat according to the Traffic Light Labelling9 ${ }^{9}$, per $100 \mathrm{~g}$ of product. Brazil, 2014.

\begin{tabular}{|c|c|c|c|c|c|c|c|}
\hline \multirow{2}{*}{ Food } & Energy value (kcal) & Sugar (g) & Total fat (g) & Saturated fat (g) & Trans fat (g) & Fiber (g) & Sodium (mg) \\
\hline & \multicolumn{7}{|c|}{$(100 \mathrm{~g})$} \\
\hline Chocolate & 505 & Red (57.0) & $\operatorname{Red}(24.7)$ & Red (13.8) & Green (0.0) & $\operatorname{Red}(0.0)$ & Red (152.8) \\
\hline Ice cream & 224 & * & Yellow (8.4) & Red (5.6) & Green (0.0) & $\operatorname{Red}(0.8)$ & Yellow (59.0) \\
\hline Stuffed cookies & 490 & * & Red (23.7) & Red (11.3) & Green (0.0) & Yellow (3.1) & Red (255.9) \\
\hline Instant noodles & 433 & * & Yellow (7.25) & $\operatorname{Red}(7.2)$ & Green (0.0) & $\operatorname{Red}(1.7)$ & Red (2145.2) \\
\hline Snack chips & 475 & * & Red (21.8) & $\operatorname{Red}(6.9)$ & Green $(0.0)$ & Yellow (3.1) & $\operatorname{Red}(756.0)$ \\
\hline Encased meat & 246 & * & Yellow (17.5) & $\operatorname{Red}(6.0)$ & Green (0.0) & $\operatorname{Red}(0.9)$ & Red (1388.6) \\
\hline
\end{tabular}

Note: *Unidentified nutritional value in the food label.

total fat; chocolate, ice cream, encased meat, and instant noodles had inadequate amount of fiber. Moreover, all foods were classified as green for trans fat.

\section{I SCUSSIO N}

It is believed that the data obtained reflect the reality of daycare centers of São Paulo since, although probability sampling techinique was not applied in the present study, the day care center sample used represents these institutions.

With regard to the limitations of the present research, since it is a cross-sectional study, the information about the food introduction age provided by mothers or guardians was based on their memory recall, which could lead to inaccuracies or recall bias. However, it is believed that the results were not significantly influenced since food introduction occurred only a few months before the interview.

Ultra-processed foods are, in general, inexpensive and are considered hyper-palatable although having high energy density. The literature strongly suggests that the high energy level and the additives present in such foods are important are risk factros for high incidence of overweight, and they also affect the total energy and fat levels in the diet ${ }^{11}$.

The results obtained in the current study revealed an early introduction of all ultra-processed foods analyzed in the children's diet. Similarly, Bernardi et al. ${ }^{12}$ investigated the introduction of this kind of food in 2,857 infants in a large Brazilian urban center, and they identified the introduction of unhealthy food (junk food) to infants younger than 10 months and the introduction of snack chips, sweets, and soda, before their first year of life. 
Specifically regarding salty foods, the results revealed that $21.5 \%$ of the mothers introduced instant noodles before their children were sixth months old and 8.6 and $7.9 \%$, respectively, introduced snack chips and encased meat before their before their first year of life. According to the Ministry of Health, feeding should be restricted to the consumption of breast milk during this period.

Moodie et al..$^{13}$ compiled trends in the purchases of processed foods in low- and middleincome countries, including Brazil, and highincome countries. They found an emphatic annual per capita consumption growth between 1997 and 2009 , with a $2.0 \%$ increase in the low- and middle-income countries and $1.4 \%$ in high-income countries. These data show that the excessive consumption of these foods is not particularly a Brazilian problem.

It is worth emphasizing that annual world production of instant noodles, considered as one of the most important Japanese inventions of the $20^{\text {th }}$ century in the food industry, is 85.6 billion servings. Especially in the Brazilian market, its sales exceeded $\mathrm{R} \$ 1.5$ billion, representing $14 \%$ of the national consumption of pasta. Over $70 \%$ of noodle consumers come from low income households (C, D, and E classes), and are considered the most susceptible to make inadequate food choices due to their low education levels ${ }^{14}$.

The abovementioned data corroborate the prospective study by Caetano et al. ${ }^{6}$ that identified, through a 7-day dietary record applied to samples of infants living in Curitiba (PR), São Paulo (SP), and Recife (PE), a weekly consumption frequency of instant noodles of 12.3 and $16.3 \%$ among infants younger and older than 6 months, respectively. These findings, in addition to the presence of other unsuitable foods for their age, revealed the inadequate amount of micronutrients, which was greater than $15.0 \%$ for calcium, $40.0 \%$ for iron, and $10.0 \%$ for vitamin C.

At the same time, Spinelli et al. ${ }^{15}$ investigated the presence of foods considered as superfluous in the diet of 400 children under one year old treated at Basic Health Units in a large municipality of São Paulo. These authors found that $63.7 \%$ of the infants consumed instant noodles and $23.0 \%$ of them had consumed it since they were 4 months old. Their study also indicated that hot dog, sausages, bologna, and salami was present in the diet of 37.9, 15.3, 4.0, and $1.6 \%$ of children under one year old, respectively.

This is of great concern since instant noodles and processed meats were classified as red for total and saturated fats and sodium, according to the Traffic Light Labelling. Thus, their consumption is strongly associated with risk for health problems, especially regarding predisposition to obesity and NCD, including diabetes, hypertension and cardiovascular diseases ${ }^{16}$.

It is important to notice that these are foods supposedly eaten at main meals, replacing a full meal and/or meat intake, thus leading not only to high consumption of energy, fats and sodium, but also to the low intake of micronutrients, especially iron. Such practice, if constant, may increase the risk of developing iron deficiency anemia, which is a nutritional deficiency considered as a global public health problem affecting $24.1 \%$ of Brazilian children under two years old ${ }^{17}$.

Regarding the introduction of sweet tasting ultra-processed foods, the results revealed that more than $67.1 \%$ of the children evaluated consumed chocolate, $68.7 \%$ stuffed cookies, and $36.9 \%$ ice cream before their first year of life. It was also found that they were offered this kind of food before their sixth month of age.

Similar results were found by Marques et al. ${ }^{18}$ who assessed the diet of 320 infants treated at Basic Health Units of Belém, State of Pará. They found that about 1/4 of the children had consumed stuffed cookies in the 24 hours preceding the survey. Accordingly, a research conducted in the metropolitan area of São Paulo showed that $50 \%$ of the children between six months and one year old consume sweets frequently in their $\operatorname{diet}^{15}$. 
Although the data obtained in the present study are related to children from the public school system and from low income families, similar situation is observed in children from private schools, in São Paulo (SP). Matuk et al. ${ }^{19}$ found that $51 \%$ of preschooler lunchboxes were filled with crackers, cookies, and cakes, 20\% with sweets, snack chips, and fried foods, and 35\% with cold cuts. Corroborating these data, a research conducted in a Brazilian private school revealed that stuffed cookies were the most common (33\%) food in children's lunchboxes ${ }^{20}$.

Regarding the classification of the amount of sugar in these foods, according to the Traffic Light Labelling, chocolate carried the red sign. Despite the impossibility of classifying the levels of sugar in the other products due to the lack of information on the nutrition fact labels, it is assumed that they are also present in excessive amounts in most of the analyzed foods, such as stuffed cookies and ice cream.

It is worth stressing that the manufacturers refused to report the amount of sugar in their products, awakening to the need for policies that make manufacturers include such information on nutrition facts labels or that force them, under the threat of punishment, to provide the information when requested by the consumer.

Kranz et al. ${ }^{21}$ studied the contribution of different food groups to added sugar intake among American children under five years old, and they found that for more than half of them, the consumption was higher than $16.0 \%$ of the total dietary energy, and $15.2 \%$ derived from high-fat desserts such as ice cream, pies, cookies, and cakes.

These findings raise concerns because sugar intake is associated, in general, lower diet quality, early onset of overweight and obesity, and the development of chronic NCD and their risk factors ${ }^{22}$. It contributes to the occurrence of dental decay $^{23}$, a fact proven by Biral et a. ${ }^{24}$, who assessed the children that participated in the 2007 data collection of the present study and found that $77.00 \%$ of them showed some change according to modified, decayed, missing, and filled teeth index (ceo-mod $\geq 1$ ) and $72.37 \%$ had dental plaque.

It is worth highlighting that although they have sweet taste, stuffed cookies and chocolates were rated red for total and saturated fats and sodium, which shows excessive content of these nutrients, and therefore they should be consumed sporadically.

Regarding the classification of foods for trans fat, $100 \%$ of the foods evaluated were rated green. It is important to notice that, according to the Technical Regulation on Nutritional Labeling of Packaged Foods ${ }^{25}$, the information of a nutrient can be expressed in "zero" or "0" or "does not contain" when the food contains amounts lower than or equal to those established as "not significant". Thus, if there are amounts lower than or equal to $0.2 \mathrm{~g}$ of trans fat in a food serving, the manufacturer can omit this information. It is concluded, therefore, that the results from the analysis of this nutrient presented in the current study, cannot portray the reality. One hundred $(100 \mathrm{~g})$ grams of food might have a higher amount of trans fat than that recognized by the nutrition labeling, which often refers to amounts way below $100 \mathrm{~g}$.

It is noteworthy that the Agência Nacional de Vigilância Sanitária (Anvisa, National Health Surveillance Agency) allows a nutrient content variation of approximately $20 \%$ between the nutrition facts label and the actual value, which can be considered as overly permissive when it relates to nutrients whose consumption is damaging to the health, for example trans fat, saturated fat, sodium, and sugar ${ }^{26}$.

Violation and problems with the rules for food product labeling is a matter of concern since they lead to the unaware consumption of trans fat, which is associated with the occurrence of cardiovascular diseases, a consequence of increased total cholesterol, Low Density Lipoprotein - cholesterol (LDL-C), and decreased High Density Lipoprotein - cholesterol (HDL-C) ${ }^{27}$. 
It is known that dietary choices and habits are determined by several variables, and this is a multi-determined process that includes a dynamic and constructed personal system ${ }^{28}$. Based on it, Furst et al. ${ }^{29}$ developed a theoretical model which illustrates the food choice process. The model comprises three components: the course of life, the influences and the personal system. Consumers can be attracted to the easiness and high palatability of ultra-processed foods; therefore, informing them of the harm inflicted by this kind of food inflict on human health, can influence their purchase decision.

Thus, if on the one hand individuals may be attracted to the palatability and convenience of ultra-processed foods, clarifying and explaining the harmful effects from consuming these foods can influence consumers' decision of whether or not to purchase them.

Accordingly, although the Traffic Light Labelling antagonizes the food industry's commercial interests, there is no prediction on whether it will be voluntarily or mandatorily applied to the labelling requirements of these foods in Brazil; it can be considered as a viable and relevant strategy for actions aimed at dietary and nutritional education, especially in daycare and basic health care centers. Knowing and understanding the nutritional profile of foods can contribute to keep mothers and guardians aware of and informed about these foods' inadequate nutritional composition, thus discouraging their premature introduction and continuous presence in children's diet favoring the promotion of an adequate and healthy diet.

This statement was proven by a research conducted with 2,932 consumers in the United Kingdom, in which it was found that the nutritional labeling interpretation was favored by the Traffic Light Labelling (71\% comprehension) when compared to the traditional labeling (58\% comprehension) ${ }^{30}$.

Another study conducted in Australia with 790 consumers of all socioeconomic classes showed that $81 \%$ of the respondents were able to correctly choose the healthiest foods and to quickly compare two products using the Traffic Light Labelling. There was a statistically significant difference between the performance with the use of the Traffic Light Labelling and that using the traditional nutrition labeling ${ }^{31}$.

The companies that have already expressed the desire to adopt the new label account for over $60 \%$ of the food sold in the United Kingdom.

It must be clarified that the labels do not have the aim to demonize foods with too many red light signals, but to give the consumers knowledge and assurance of safety and quality of what they are acquiring.

In addition, it is believed that an increase in the use of this tool can positively contribute to the efforts made by the industry to improve their products' nutritional composition aiming at green sign rates.

According to this perspective, it should be noticed that the "Plano de ações estratégicas para o enfrentamento das Doenças Crônicas Não Transmissíveis (DCNT) no Brasil 2011-2022" ("Strategic action plans for addressing NCD, 2011-2022)" establishes the promotion of healthy eating as its main action. Among its goals, there is the establishment of agreements with the food industry in order to reduce the amount of salt and sugar in processed foods and to restrict the marketing of foods and beverages high in salt, fat and sugar, especially for children ${ }^{32}$.

Correspondingly, the Associação Brasileira das Indústrias da Alimentação (ABIA, Brazilian Association of Food Industries) and the Ministry of Health have signed a pact to reduce the sodium content in ultra-processed foods, including foods such as sausages, pasta, cakes, crackers, cookies, and broths. It is also expected to decrease $68 \%$ in dairy products, processed meats, and ready to eat meals thus providing a reduction of 28 thousand tons of sodium in the market by 2020 . However, it is noteworthy that the adherence to the agreement is voluntary, and the inspection can occur by examining food labels, information passed on by the industry, or lab evaluation ${ }^{33}$. 
Although the agreement between the public and private sector seems to be a promising strategy, Moodie et al. ${ }^{13}$, in a publication in favor of The Lancet NCD Action Group, argue that the industry uses a series of strategies to minimize the effects of public health policies (such as the funding of research and scientific conferences on health and the sponsorship of events related to physical activity) by encouraging votes opposing regulations and arguing that government interventions are coercive and oppress the individuals' freedom of choice and responsibility. According to this approach, and consequently, with less support from the civil society, the adoption of regulatory measures, such as restriction warning, and increase in industrialized product tax, have become more difficult or even infeasible.

\section{CONCLUSION}

The data obtained in the present study showed that the introduction of ultra-processed foods occurred early in the diet of infants evaluated. The nutritional composition of the foods analyzed proved they were high in total fat, saturated fat, and sodium, which, according to the Traffic Light Labelling, disregards the recommendations of adequate and healthy diet for children in this age group.

Therefore, this highlighted the need for public health measures based on strategies for nutritional education and regulation and inspection of food industries, both concerning the composition of foods and their nutrition labeling. These strategies would be a tool to acquire and keep healthy eating habits and positively contribute to the proper growth and development of children and prevent the increase of overweight, obesity, and chronic diseases in the short, medium, and long term. They would be a key tool in the fight against the rampant growth of diseases considered major public health problems to be tackled.

\section{CONTRIBUTORS}

G LONGO-SILVA contributed to the conception and design of this study, data analysis and interpretation, and manuscript writing. MHA TOLONI contributed to the conception and design of the study, data analysis and interpretation, and final revision of the manuscript submitted for publication. RCE MENEZES, L ASAKURA and MAA OLIVEIRA contributed to the data analysis and interpretation and writing and revision of the manuscript. JAAC TADEI contributed to the conception and design and the final revision of the manuscript submitted for publication.

\section{REFERE NCES}

1. Kramer MS, Kakuma R. The optimal duration of exclusive breastfeeding: A systematic review. Geneva: WHO; 2002 [cited 2014 Feb 5]. Available from: http://www.who.int/nutrition/topics/optimal_ duration_of_exc_bfeeding_review_eng.pdf

2. Brasil. Ministério da Saúde. Secretaria de Atenção à Saúde.Dez passos para uma alimentação saudável: guia alimentar para crianças menores de dois anos: um guia para o profissional da saúde na atenção básica. $2^{a}$ ed. Brasília: Ministério da Saúde; 2013.

3. Jackson P, Romo M, Castillo M, Castillo-Durán C. Las golosinas en la alimentación infantil: análisis antropológico nutricional. Rev Méd Chile. 2004; 132:1235-42. http://dx.doi.org/10.4067/S0370-4 1062006000200011

4. Monteiro CA, Levy RB, Claro RM, Castro IRR, Cannon G. A new classification of foods based on the extent and purpose of their processing. Cad Saúde Pública. 2010; 26(11):2039-49. http://dx. doi.org/10.1590/S0102-311X2010001100005

5. Toloni MHA, Longo-Silva G, Goulart RMM, Taddei JAAC. Introdução de alimentos industrializados e de alimentos de uso tradicional na dieta de crianças de creches públicas no município de São Paulo. Rev Nutr. 2011; 24(1):61-70. http://dx. doi.org/10.1590/ S1415-52732011000100006

6. Caetano MC, Ortiz TT, Silva SG, Souza FI, Sarni RO. Complementary feeding: Inappropriate practices in infants. J Pediatr. 2010; 86:196-201. http://dx.doi. org/10.1590/S0021-75572010000300006

7. Toloni MHA, Longo-Silva G, Pontes TE, Taddei JAAC. Rotulagem e publicidade de alimentos. In: Taddei JAAC, Lang RMF, Longo-Silva G, Toloni MHA, editores. Nutrição em saúde pública. Rio de Janeiro: Rubio; 2013. 
8. Food Standards Agency. Food labels: Traffic light labelling. London: 2007 [cited 2014 Jan 20]. Available from: http://www.eatwell.gov.uk

9. Longo-Silva G, Toloni MHA, Taddei JAAC. Traffic light labelling: traduzindo a rotulagem de alimentos. Rev Nutr. 2010; 23(6):1031-40. http:// dx.doi.org/10.1590/S1415-52732010000600009

10. Beghin I, Cap M, Dujardin B. A guide to nutritional assessment. Geneva: World Health Organization; 1988.

11. Rausser BMG. Does food processing contribute to childhood obesity disparates? Am J Agr Econ. 2005; 87(5):1154-8.

12. Bernardi JLD, Jordão RE, Barros Filho AA. Alimentação complementar de lactentes em uma cidade desenvolvida no contexto de um país em desenvolvimento. Rev Panam Salud Publica. 2009; 26(5):405-11. http://dx.doi.org/10.1590/S1020-4 9892009001100004

13. Moodie R, Stuckler D, Monteiro C, Sheron N, Neal $B$, Thamarangsi $T$, et al. Prots and pandemics: Prevention of harmful effects of tobacco, alcohol, and ultra-processed food and drink industries. The Lancet. 2013; 381(9867):670-9. http://dx.doi.org/ 0.1016/S0140-6736(12)62089-3

14. Toloni MHA, Longo-Silva G, Konstantyner T, Taddei JAAC. Consumo de alimentos industrializados por lactentes matriculados em creches. Rev Paul Pediatr. 2014; 32(1):37-43. http://dx.doi.org/10.1590/S0 103-05822014000100007

15. Spinelli MGN, Souza SB, Souza JMP. Consumo, por crianças menores de um ano de idade, de alimentos industrializados considerados supérfluos. Rev Pediatr Mod. 2011; 37(12):666-72.

16. Monteiro CA, Levy RB, Claro RM, de Castro IR, Cannon $G$. Increasing consumption of ultraprocessed food and likely impact on human health: Evidence from Brazil. Public Health Nutr. 2011; 14:5-13. http://dx.doi.org/10.1017/S1368980010 003241

17. Brasil. Ministério da Saúde. Pesquisa Nacional de Demografia e Saúde da Criança e da Mulher - PNDS 2006: dimensões do processo reprodutivo e da saúde da criança. Brasília: Ministério da Saúde; 2009.

18. Marques RSFV, Sarni ROS, Santos FPC, Brito DMP. Práticas inadequadas da alimentação complementar em lactentes, residentes em Belém - PA. Rev Para Med. 2013 [acesso 2014 mar 16]; 27(2):1-9. Disponível em: http://files.bvs.br/upload/S/0101-5 907/2013/v27n2/a3675.pdf

19. Matuk TT, Stancari PCS, Bueno MB, Zaccarelli EM. Composição de lancheiras de alunos de escolas particulares de São Paulo. Rev Paul Pediatr. 2011;
29(2):157-63. http://dx.doi.org/10.1590/S0103-05 822011000200005

20. Campos JA, Zuanon AC. School lunch and health promotion. Ciênc Odontol Bras. 2004; 7:7-71. http://dx.doi.org/10.1017/S1368980010001199

21. Kranz S, Smiciklas-Wright $H$, Sega-Riz AM, Mitchell $D$. Adverse effect of high added sugar consumption on dietary intake in American preschoolers. J Pediatr. 2005; 146(1):105-11. http://dx.doi.org/ 10.1016/j.jpeds.2004.08.077

22. Fung TT, Malik V, Rexrode KM, Manson JE, Willett WC, Hu FB. Sweetened beverage consumption and risk of coronary heart disease in women. Am J Clin Nutr. 2009; 89(4):1037-42. http://dx.doi.org/10.39 45/ajcn.2008.27140

23. Yabao RN, Duante CA, Velandria FV, Lucas M, Kassu A, Nakamori $M$, et al. Prevalence of dental caries and sugar consumption among 6-12-y-old schoolchildren in La Trinidad, Benguet, Philippines. Eur J Clin Nutr. 2005; 59:1429-38. http://dx.doi. org/10.1038/sj.ejcn. 1602258

24. Biral AM, Taddei JAAC, Passoni DF, Palma D. Cárie dentária e práticas alimentares entre crianças de creches do município de São Paulo. Rev Nutr. 2013; 26(1):37-48. http://dx.doi.org/10.1590/S1415-527 32013000100004

25. Agência Nacional de Vigilância Sanitária. Resolução RDC n³59, de 23 de dezembro de 2003. Regulamento técnico de porções de alimentos embalados para fins de rotulagem nutricional. Brasília: Ministério da Saúde; 2003 [acesso 2014 fev 20]. Disponível em: http://e-legis.bvs.br/leisref/public/ showAct.php?id=9058

26. Agência Nacional de Vigilância Sanitária. Resolução RDC n³60, de 23 de dezembro de 2003. Regulamento técnico sobre rotulagem nutricional de alimentos embalados. Brasília: Anvisa; 2003 [acesso 2014 jan 10]. Disponível em http://portal.anvisa. gov.br/wps/wcm/connect/ec3966804ac02cf196 2abfa337abae9d/Resolucao_RDC_n_360de_23_ de_dezembro_de_2003.pdf?MOD=AJPERES

27. Chiara VL, Silva R, Jorge R, Brasil AP. Ácidos graxos trans: doenças cardiovasculares e saúde maternoinfantil. Rev Nutr. 2002; 15(3):341-9. http://dx.doi. org/10.1590/S1415-52732002000300010

28. Jomori MM, Proença RPC, Calvo MCM. Determinantes de escolha alimentar. Rev Nutr. 2008; 21(1):63-73. http://dx.doi.org/10.1590/\$1415-52 732008000100007

29. Furst T, Connors M, Bissogni CA, Sobal J, Falk LW. Food choice: A conceptual model of the process. Appetite. 1996; 26(3):247-66. http://dx.doi.org/ 10.1006/appe. 1996.0019 
30. Food Standards Agency. Compreension and use of UK nutrition signpost labeling shemes. London: Food Standards Agency; 2009 [cited 2014 Jan 13]. Available from: http://multimedia.food.gov.uk/ multimedia/pdfs/pmpreport.pdf

31. Kelly B, Hughes C, Chapman K, Louie J, Dixon H, King L. On behalf of a collaboration of Public Health and Consumer Research Groups. Front-of-pack food labelling: Traffic light labelling gets the green light. Sydney: Cancer Council; 2008.

32. Brasil. Ministério da Saúde. Secretaria de Vigilância em Saúde. Plano de ações estratégicas para o enfrentamento das Doenças Crônicas Não Trans- missíveis (DCNT) no Brasil 2011-2022. Brasília: Ministério da Saúde; 2011.

33. Brasil. Ministério da Saúde. Portal de Atenção Básica. Promoção da saúde e da alimentação adequada e saudável: redução de sódio, açúcar e gordura trans - 2013/2014. Brasília: Ministério da Saúde; 2014 [acesso 2014 jan 15]. Disponível em: http:// dab.saude.gov.br/portaldab/ape_promocao_ da_saude.php?conteudo=reducao

Received: January 25, 2015 Final version: July 19, 2015 Approved: May 25, 2015 
